\title{
KONSEP AL-BAAQIYAAT AS-SHOLIHAT DALAM MURABAHAH: PENENTUAN MARGIN SERTA PENGGUNAAN METODE PERHITUNGAN ANUITAS DAN FLAT
}

\author{
Angga Arisa \\ UIN Sunan Gunung Djati Bandung, Bandung, Indonesia \\ Email:namakuanggaarisa@gmail.com
}

\begin{abstract}
Murabahah is a financing that dominates the Islamic banking portfolio in Indonesia until the position of September 2018. However, the total amount of murabahah finan cing is still very small when compared to conventional bank lending. One of the issues that must be sought a solution in order to accelerate the growth of Islamic bank business is the issue of murabah a conformity with sharia provisions, namely in the aspect of adding margins in murabaha and the use of annuity and flat methods in calculating margins. Therefore, the activities of Islamic banks in conducting murabaha financing need to be seen as wealth management / accumulation activities of Islamic banks as economic subjects. This approach to the management of assets can refer to Al-kahfi verse 46, where assets must be managed in ways that are in accordance with sharia so that they are valued as al-baaqiyatas-sholihat (good deeds). With the concept of al-baaqiyat as-sholihat, the addition of margins and the use of annuity and flat methods can be in accordance with sharia principles so that murabaha financing activities become valuable charity. This aims to accelerate the growth of murabaha and the growth of Islamic banks themselves so that more people can access Islamic banking.
\end{abstract}

Keywords: Al-baaqiyaat As-sholihat, Annuity, Flat, Margin, Murabahah

\begin{abstract}
ABSTRAK
Murabahah merupakan pembiayaan yang mendominasi portofolio perbankan syariah di Indonesia sampai dengan posisi September 2018. Akan tetapi, total jumlah pembiayaan murabahah masih sangat kecil jika dibandingkan dengan penyaluran kredit perbankan konvensional. Salah satu isu yang harus dicarikan solusi supaya bisa mengakselerasi pertumbuhan bisnis bank syariah adalah isu kesesuaian murabahah dengan ketentuan syariah, yaitu dalam aspek penambahan margin dalam murabahah serta penggunaan metode anuitas dan flat dalam menghitung margin. Oleh karena itu, kegiatan bank syariah dalam melakukan pembiayaan murabahah perlu dilihat sebagai kegiatan pengelolaan harta (wealth creation/accumulation) bank syariah selaku subjek ekonomi. Pendekatan konsep pengelolaan harta ini bisa merujuk pada surat Al-kahfi ayat 46, dimana harta harus dikelola dengan cara-cara yang sesuai dengan syariah supaya bernilai sebagai al-baaqiyat as-sholihat (amal sholeh). Denga konsep al-baaqiyat as-sholihat ini maka penambahan margin dan penggunaan metode anuitas dan flatdapat menjadi sesuai dengan kaidah syariah sehingga kegiatan pembiayaan murabahah menjadi bernilai amal sholeh. Hal ini bertujuan untuk mengakselerasi pertumbuhan murabahah serta pertumbuhan bank syariah itu sendiri sehingga semakin banyak masyarakat yang bisa mengakses perbankan syariah.
\end{abstract}

Kata kunci: Al-baaqiyaatAs-sholihat, Annuity, Flat, Margin, Murabahah

* Copyright (c) 2020 Angga Arisa

This work is licensed under a Creative Commons Attribution-ShareAlike 4.0 International License. 
Khazanah Pendidikan Islam, Vol. 2 No. 3: 139-149

Konsep Al-Baaqiyaat As-Sholihat Dalam Murabahah: Penentuan Margin Serta Penggunaan Metode Perhitungan Anuitas Dan Flat

Angga Arisa

\section{PENDAHULUAN}

Murabahah merupakan akad jual beliatas suatu barang dengan menambahkan margin (kelebihan harga) selain harga pokok barangtersebut (Turmudi, 2016). Dalam murabahah, harga pokok atas barang objek jualbeli tersebut harus diketahui antara penjual dan pembeli,kemudian besaran margin juga harus disepakati oleh penjual dan pembeli tersebut. Kaidah-kaidah yang terdapat dalam murabahah harus memenuhi rukun dan syarat jual beli. Rukun jual beli terdiri atas 2 orang ( 2 pihak) yang melakukan akad, sighat (ijab qobul), serta objek akad (barang yang diperjualbelikan) (Suprihatin et al., 2019). Sedangkan syarat sah jual beli terdiriatas 6 hal, yaitu: saling ridho antara pejual dan pembeli; para pihak (penjual dan pembeli) cakap secara syariah untuk melakukan transaksijual beli; barangyang diperjualbelikan bernilai (berharga) dan tidak diharamkan menurut syariat Islam; barang yang diperjual belikan adalah milik sendiri atau sudah dikuasakan dari pemilik ke penjual (wakalah); barang yang diperjualbelikan dapat diserahterimakan (transfer kepemilikan); serta barang tersebut dapat diketahui secara pasti kadar, jumlah, ukuran, dannilainya (tidak ghoror) (Suprihatin etal.,2019).

Dalam konteks perbankan syariah, murabahah merupakan salah satu akad (kontrak) yang ada di bank syariah selain mudharabah (Adnan \& Purwoko, 2015), musyarakah, wadiah, ijaroh, istishna', qordh, dan lainnya. Dilihat dari sudut pandang laporan keuangan bank syariah (dalam hal ini adalah neraca), murabahah terletak di sisi aktiva bersamaan dengan mudharabah, musyarokah, istishna', qordh, dan ijaroh (Nisa, 2020). Sedangkan akad yang terletak di sisi pasiva adalah mudharabah dan wadiah. Untuk mudharabah, akad ini bisa terdapat di sisi aktiva dimana bank syariah berperan sebagai pemilik dana (sohibul maal), serta bisa terdapat di sisi pasiva dimana bank syariah berperan sebagai pengelola dana (mudharib).

Secara akuntansi, karena murabahah terletak di sisi aktiva maka murabahah dapat dilihat sebagai instrumen yang digunakan bank syariah untuk mendapatkan pendapatan/keuntungan/laba. Pendapatan yang dihasilkan mu rabahah berasal dari penambahan margin pada harga pokok objek jual beli,sehingga murabahah juga dikenal dengan istilah jual beli dengantambahan (markup) (Annisa, 2013). Hal ini tidak hanya berlaku untuk murabahah, semua akad di sisi aktiva juga ditujukan untuk menghasilkan pendapatan, yaitu: bagi hasil (baik profit sharing maupun revenue sharing) dalam mudharabah dan musyarokah, serta ujroh dalam ijaroh. Khusus untuk akad qordh, bank syariah tidak boleh mengambil keuntungan secaralangsung karena kelebihan atas nominal qordh adalah riba.

Walaupun instrumen yang menghasilkan pendapatan tidak hanya murabahah, tetapi berdasarkan data di Statistik Perbankan Syariah September 2018 (ojk, 2018), portofolio murabahah di perbankan syariah Indonesia sangat besar. Pada posisi Desember 2016 jumlah pembiayaan murabahah adalah Rp 110,101 Trilyun, pada posisi Desember 2017 jumlah pembiayaan murabahah Rp 114,534 Trilyun (pertumbuhan year on year sebesar 4\%), kemudian pada posisiSeptember 2018 pembiayaan murabahah Rp 118,810 Trilyun (pertumbuhan year to date sebesar 3,7\%). Jika dibandingkan dengan pembiayaan syariah yang lainnya (mudharabah, musyarokah, istishna', qordh, dan ijaroh), portofolio pembiayaan murabahah ini adalah 62\% pada posisi Desember 2016, serta 60\% pada posisi Desember 2017 dan September 2018. Portofolio pembiayaan syariah dari tahun 2016 sampai dengan 2018 tersebut dapat dilihatpada Gambar 1. 
Khazanah Pendidikan Islam, Vol. 2 No. 3: 139-149

Konsep Al-Baaqiyaat As-Sholihat Dalam Murabahah: Penentuan Margin Serta Penggunaan Metode Perhitungan Anuitas Dan Flat

Angga Arisa

\begin{tabular}{|l|r|r|r|r|r|}
\hline $\begin{array}{c}\text { Jenis } \\
\text { Pembiayaan }\end{array}$ & $\begin{array}{c}\text { Des 2016 } \\
\text { (Rp Milyar) }\end{array}$ & $\begin{array}{c}\text { Des 2017 } \\
\text { (Rp Milyar) }\end{array}$ & $\begin{array}{c}\text { Year on } \\
\text { Year }\end{array}$ & $\begin{array}{c}\text { Sept 2018 } \\
\text { (Rp Milyar) }\end{array}$ & $\begin{array}{c}\text { Year to } \\
\text { Date }\end{array}$ \\
\hline Mudharabah & 8.012 & 7.050 & $-12,0 \%$ & 6.045 & $-14,3 \%$ \\
\hline Musyarakah & 54.139 & 60.486 & $11,7 \%$ & 64.711 & $7,0 \%$ \\
\hline Murabahah & 110.101 & 114.534 & $4,0 \%$ & 118.810 & $3,7 \%$ \\
\hline Qordh & 3.883 & 5.476 & $41,0 \%$ & 6.223 & $13,6 \%$ \\
\hline Istishna' & 25 & 18 & $-28,0 \%$ & 16 & $-11,1 \%$ \\
\hline ljaroh & 1.883 & 2.791 & $48,2 \%$ & 3.227 & $15,6 \%$ \\
\hline Total & $\mathbf{1 7 8 . 0 4 3}$ & $\mathbf{1 9 0 . 3 5 5}$ & & $\mathbf{1 9 9 . 0 3 2}$ & \\
\hline
\end{tabular}

Gambar 1. Portofolio Pembiayaan Perbankan Syariah di Indonesia

Data tersebut di atas menunjukan besarnya portofolio murabahah di perbankan syariah Indonesia. Fenomena ini dapat dijelaskan dari sisi bank syariah ataupun sisi nasabah. Dari sisi bank syariah, murabahah fleksibel digunakan untuk beberapa skim pembiayaan, baik pembiayaan konsumtif maupun untuk modal kerja dan investasi. Kemudian, dari sisi akuntansi murabahah juga sederhana dan metode perhitungannya bisa menggunakan pendekatan yang sama seperti kredit di perbankan konvensional, berbeda dengan mudharabah dan musyarokah yang secara akuntansi lebih rumit dibandingkan murabahah. Dari sisi nasabah, konsep jual beli dalam murabahah juga paling mudah dipahami dibandingkan dengan konsep penyertaan modal dalam mudharabah dan musyarokah.

Jika dibandingkan dengan penyaluran kredit perbankan konvensional di Indonesia, jumlah pembiayaan murabahah bahkan total pembiayaan syariah masih sangat kecil. Pada posisi September 2018 total penyaluran kredit mencapaiangka Rp 5.175,052 Trilyun (ojk, 2018). Hal ini berarti, komposisi pembiayaan syariah pada posisi September 2018 baru sebesar 3,8\% dibandingkan total penyaluran kredit perbankan konvensional, sedangkan komposisi pembiayaan murabahah posisi September 2018 baru sebesar 2,3\% dibandingkan total penyaluran kredit perbankan konvensional. Walaupun angkanya masih kecil, tetapi karena portofolio murabahah dibandingkan total pembiayaan syariah adalah $60 \%$, maka murabahah mempunyai peranan yang sangat penting dalam membesarkan bank syariah. Akan tetapi, dalam praktiknya masih ditemukan beberapa hal yang menghambat pertumbuhan murabahah, diantaranya adalah isu tidak syariahnya mu rabahah di bank syariah. Beberapa alasan yang dikemukakan nasabah dan calon nasabah bank syariah terkaittidak syariahnya murabahah ini adalah sebagai berikut:

1. Bank syariah mendapatkan keuntungan (margin) dari pembiayaan murabahah bahkan di beberapa bank syariah besaran margin ini lebih besar daripada bunga bank kon vensional.

2. Bank syariah menggunakan pendekatan prosentase (\%) dalam menentukan besaran margin, bahkan dalam teknis perhitungannya metode angsurannya menggunakan perhitungan anuitas dan flat untuk menentukan nominal angsuran, nominal pokok, dan nominal margin.

Selain kedua isu tersebutsebenarnya masih terdapat isu-isulain terkait pembiayaan murabahah di bank syariah, tetapi yang dominan dan bobotnya lebih tinggi adalah kedua isu tersebut. Hal ini dikarenakan kedua isu tersebut menyentuh aspek mendasar pembiayaan di bank syariah yang harus bebas bunga, bebas dariunsurjudi, dan bebas dari unsur ketidakpastian (bebas ghoror). 
Khazanah Pendidikan Islam, Vol. 2 No. 3: 139-149

Konsep Al-Baaqiyaat As-Sholihat Dalam Murabahah: Penentuan Margin Serta Penggunaan Metode Perhitungan Anuitas Dan Flat

Angga Arisa

\section{METODE PENELITIAN}

Penelitian ini menggunakan pendekatan kualitatif (Sugiyono, 2013) dengan menggunakan Metode Tafsir Tematik( (Hidayatulloh,2018) untuk memperoleh data - data primeryang nantinya akan penulis uraikan dalam kal imat - kalimat secara deskriptif. Selain itu peneliti juga menggunakan studi literatur dari berbagai website pemerintah serta artikel/hasil penelitian terdahulu yang membantu penulis membuat simpulan - simpulan sebagai dasar untuk menjawab permasalahanyang penuliskemukakan.

\section{HASIL DAN PEMBAHASAN}

\section{Konsep Al-Baaqiyaat As-Sholihat}

Murabahah sebagai salah satu akad dalam pembiayaan perbankan syariah tidak bisa dilepaskan dari konsep pengelolaan harta/kekayaan dalam Islam. Secara praktis, salah satu tujuan perbankan syariah menyalurkan pembiayaan murabahah adalah untuk mendapatkan pendapatan/keuntungan/laba, dimana sumber dana yang digunakan oleh perbankan syariah untuk melakukan kegiatan pembiayaan (termasuk murabahah) adalah dari modal sendiri dan dana dari nasabah (dengan akad mudharabah ataupun wadi'ah).Oleh karenaitu, kegiatan perbankan syariah sebagai lembaga perantara (intermediary) ini dapat dilihat sebagai kegiatan pengumpulan kekayaan (wealth creation dan wealth accumulation).

Konsep tentang harta/kekayaan dalam Islam dapat dilihat dalam teks Al-qur'an berikut ini. وخير املر

"Harta dan keturunan adalah perhiasan kehidupan di dunia, tetapi amal kebajikan yang terusmenerus lebih bai pahalanya di sisi Tuhanmu sertalebih baik untuk menjadi harapan." (QS Al-kahfi: 46)

Harta dalam ayat tersebut disebutkan dengan istilah al-maalu, yaitu lafadz maalu yang merupakan bentuk tunggal yang berarti harta, kemudian ditam bah dengan aliflam sehingga maknanya menjadi segala bentuk harta (Al-Faizin \& Akbar, 2018). Setelah lafadz al-maalu dilanjutkan dengan lafadz al-banuuna yang berarti segala bentuk keturunan. Kemudian lafadz ziinatu mempunyai makna keindahan-keindahan yang disenangi manusia. Oleh karena itu penggalan pertama ayat ini bisa dimaknai bahwa harta dan keturunan itu merupakan keindahan-keindahan yang disenangi manusia. Ayat-ayat Al-qur'an yang menyebutkan tentang harta tidak hanya ayat ini. Harta disebutkan sebanyak 86 kali di dalam Al-qur'an, baik dengan lafadz al-maalu ataupun lainnya, yaitu: khoir, al-qonaatir, dan at-toyyibaat.

Kemudian, lafadz al-baaqiyat as-sholihat secara harfiah dimaknai sebagai amal kebajikan yang terus menerus. Sedangkan menurut para ahli tafsir, lafadz ini dimaknai antara lain: sholat wajib 5 waktu, dzikir, anak perem puan yang sholehah, dan amal sholeh (Al-Faizin \& Akbar, 2018). Dari 4 pengertian albaaqiyat as-sholihat tersebut, dalam kajian ekonomi bisa digunakan pengertian al-baaqiyat as-sholihat sebagaiamal sholeh. Merujuk kepada pengertiaayat tersebut, amal sholeh yang dilakukan secara kontinyu nilainya lebih baik di sisi Allah dibandingkan harta, maka harta tidak boleh membuat manusia lalai dari berbuat amal sholeh. Selain itu, dalam pengertian yang luas bahwa dalam pengelolaan harta harus bisa bernilai sebagai amal sholeh, baik dalam proses pencarian atau pengumpulan harta (wealth creation/accumulation), penggunaan harta (wealth consumption), distribusi harta (wealth distribution), dan proteksi harta (wealth protection). Supaya proses-proses tersebut bernilaiamal sholeh, maka seluruh proses tersebut harussejalan dengan syariah atau mengikuti nilai-nilai dasar dan prinsip ekonomi Islam. Oleh karena itu, dalam konteks ini al-baaqiyat as-sholihat bisa dimaknai sebagai proses pengumpulan, 
Khazanah Pendidikan Islam, Vol. 2 No. 3: 139-149

Konsep Al-Baaqiyaat As-Sholihat Dalam Murabahah: Penentuan Margin Serta Penggunaan Metode Perhitungan Anuitas Dan Flat

Angga Arisa

konsumsi, distribusi, dan proteksi hartayang bernilai amal sholeh karenasesuai dengan ketentuan syariah atau sesuai dengan nilai-nilai dasar ekonomi Islam.

\section{Al-Baaqiyaat As-Sholihat dalam Murabahah}

Seperti yang dijelaskan pada sub di atas, murabahah merupakan kegiatan yang dilakukan perbankan syariah dengan motif ekonomi,yaitu mencari keuntungan. Hal ini dapat dipahami karena bank syariah dapat dilihat sebagai subjek ekonomi. Keuntungan yang diperoleh bank syariah dari kegiatan pembiayaannya akan digunakan oleh seluruh pemangku kepentingan bank syariah tersebut, diantaranya adalah bank syariah itu sendiri, pemilik bank syariah, dan nasabah pemilik dana (sohibul maal). Dari perspektif ini, bank syariah ketika menyalurkan pembiayaan murabahah ini adalah kegiatan pencairan/pengumpulan harta yang dilakukan bank syariah.

Supaya kegiatan pencarian/pengumpulan harta ini bernilai ibadah, maka prosesnya harus mengikuti kaidah al-baaqiyat as-sholihat. Dalam konteks murabahah, maka seluruh aspek dalam murabahah harus sesuai dengan syariah supaya bisa bernilai al-baaqiyat as-sholihat sehingga harta/kekayaan yang didapatkan dari murabahah bisa mengandung barokah. Oleh karena itu, untuk mempermudah penilaian kandungan al-baaqiyat as-sholihat dalam murabahah, proses murabahah bisa dibagi 3 bagian penting, yaitu: akad, profit/margin, serta metode perhitungan margin (Rachmawati \& Darmaya, 2018).

Untuk akad, parameter kesesuaiannya dengan ketentuan syariah adalah dengan mencocokan seluruh komponen akad dengan rukun jual beli dan syarat sah jual beli. Jika seluruhnya terpenuhi, akad tersebut sudah sesuai syariah sehingga akad tersebut memenuhi kaidah al-baaqiyat as-sholihat.

\section{Profit/Margin dalam Murabahah}

Salah satu yang dipermasalahkan oleh masyarakat tentang murabahah adalah profit/margin yang dikenakan dalam murabahah. Persepsi yangada di sebagian masyarakat adal ah murabahah sama dengan kredit karena murabahah mempunyai kelebihan berupa margin dan kreditmempunyai kelebihan berupa bunga. Bahkan di beberapa bank syariah, besaran margin murabahah bisa lebih besar daripada nominal bunga bank konvensional. Asumsinya adalah pembiayaan syariah seharusnya tidak mengenakan kelebihan dalam bentuk apapun dan istilah apapun. Ditambah lagi fakta di beberapa bank syariah, besaran margin murabahah ini diekuivalenkan dengan prosentase (\%) dari pokok nominal murabahah sehingga semakin membuat persepsitersebutteramplifikasi.

Secara prinsip, hal ini dapat dijelaskan dengan pendekatan surat Al-Baqoroh ayat 275, dimana dinyatakan bahwa Allah menghalalkan jual beli dan megharamkan riba. Maknanya adalah jual beli dan semua turunannya adalah halal.Turunanjual beli disini bisa dimaknai secaraluas antara lain: semua jenis jual beli sepanjang memenuhi rukun dan syarah sah jual beli, serta keuntungan/margin yang diperoleh penjual daritransaksi jual beli.

Setelah jelas bahwa margin dari transaksi jual beli adalah halal, kemudian yang menjadi isu juga adalah besaran keuntungan/margin. Margin dalam murabahah merupakan komponen dari harga jual objek murabahah dari bank syariah ke nasabah. Oleh karena itu, pembahasan mengenai margin ini bisa dilihat dari 2 perspektif, yaitu: perspektif profit dan perspektif penetapan harga. Supaya murabahah ini bernilai al-baaqiyat as-sholihat maka profit dan penetapan harga ini harus dikaji berdasarkan ketentuan syariah. 
Khazanah Pendidikan Islam, Vol. 2 No. 3: 139-149

Konsep Al-Baaqiyaat As-Sholihat Dalam Murabahah: Penentuan Margin Serta Penggunaan Metode Perhitungan Anuitas Dan Flat

Angga Arisa

Dalam perspektif profit, perlu dikaji dalil-dalil nash (Al-qur'an dan As-sunnah) yang menentukan besaran profit.Yusuf Al-qardhawi menyatakan bahwa hasil kajian terhadap ayat-ayat Al-qur'an dan hadits tidak ada yang menyatakan batasan maksimal profit yang boleh diambil (Isnaini \& Marliyah, 2015). Bahkan terdapat hadits yang diriwayatkan oleh Urwah Al-bariqi yang menyatakan bahwa Urwah pernah diberiuang 1 dinar oleh Rosulullah untuk membeli 1 ekor kambing, kemudian Urwah menggunakan uang tersebut untukmembeli 2 ekor kambing, kemudian 1 ekor kambing dijual kembali dengan harga 1 dinar (Isnaini \& Marliyah, 2015). Haditsini meriwayatkan bahwa dari transaksi tersebutUrwah mendapatkan profit sebesar 1 dinar (100\% dari modal). Selain hadits tersebut, masih terdapat hadits -hadits lain yang menceritakan proses pengambilan profit dari transaksi jual beli, tetapi tidak ada satupun yang secara eksplisit menyebutkan besaran profit, bahkan yang disebutkan adalah pengambilan keuntungan secara wajar. Oleh karena itu, dalam perspektif ini besar kecil profit dalam murabahah sebenarnya sudah memenuhi kaidah al-baaqiyatas-sholihat.

Kemudian dalam perspektif penetapan harga, sebenarnya karena besaran profit sudah tidak menjadi isu karena sudah sesuai dengan kaidah al-baaqiyat as-sholihat, penetapan harga juga otomatis secara logis pasti mengikuti kaidah al-baaqiyat as-sholihat. Hal ini dikarenakan harga merupakan hasil dari harga pokok ditambah profit yang dikenakan. Selain itu, dalam sebuah hadits juga diriwayatkan bahwa pada zaman Rosulullah pernah mengalami kenaikan harga, kemudian sahabat meminta Rosulullah utuk menetapkan standar harga, maka Rosulullah menjawab bahwaharga ditentukan oleh Allah (Isnaini \& Marliyah, 2015). Hadits ini dapat dimaknai bahwa Islam tidak menganut konsep intervensi harga jika proses pembentukan harganya sudah sesuai dengan mekanisme pasar. Dalam konteks murabahah di bank syariah, harga jual kembali objek murabahah dari bank syariah kepada nasabah yang terdiri dar komponen harga pokok ditambah margin sudah sesuai dengan kaidah al-baaqiyat as-sholihat.

Penjelasan dari 2 perspektif tersebut di atas dapat dimaknai bahwa besaran margin yang dikenakan bank syariah dalam murabahah harus mengikuti mekanisme pasar. Dikarenakan bank syariah juga berperan sebagai mu dharib dari dana-dana nasabah, maka besaran margin murabahah disesuaikan dengan struktur dana di bank syariah tersebut, semakin dominan dana murah (misalnya dana yang bersumber dari wadi'ah) maka margin murabahah bisa ditekan. Dalam prakteknya, struktur dana bukan satu-satunya faktor, tetapi ada faktor lain seperti biaya operasional bank syariah dan ekspektasi tingkat keuntungan yang ingin diperoleh bank syariah tersebut. Selain itu, walaupun bank syariah tidak memberikan bunga kepada nasabahnya, tetapi bank syariah juga secara bisnis akan terekspos risiko suku bunga. Jika suku bunga acuan naik (BI 7 Days Repo Rate) maka suku bunga simpanan perbankan konvensional akan naik juga, dampaknya adalah adanya risiko migrasi dana dari perbankan syariah ke perbankan konvensional sehingga perbankan syariah juga pada akhirnya harus bisa memberikan bagi hasil kepada nasabah simpanan yang mendekati, sama, atau lebih dari suku bunga perbankan konvensional. Hal ini jelas menjadi faktor penentuan besaran margin dalam murabahah. Kemudian, besaran margin inijuga harus kompetitif di pasar. Walaupun bank syariah sudah menetapkan sesuai dasar perhitungan di atas, pada akhirnya tetap dikembalikan kepada penerimaan pasar. Nasabah pasti akan membandingkan dengan sesama bank syariah serta dengan bank konvensional. Oleh karena itu, kaidah al-baaqiyat as-sholihat dalam penentuan margin ini harus memenuhi kedua unsur tersebut, yaitu struktur dana di bank syariah serta mekanisme pasar.

\section{Metode Perhitungan Margin dengan Metode Anuitas}

BerdasarkanPernyataan Standar Akuntansi Keuangan (PSAK) No. 102 Tahun 2007 tentangAkuntansi Murabahah, margin (keuntungan) murabahah dapat diakui dalam beberapaopsi, salah 
Khazanah Pendidikan Islam, Vol. 2 No. 3: 139-149

Konsep Al-Baaqiyaat As-Sholihat Dalam Murabahah: Penentuan Margin Serta Penggunaan Metode Perhitungan Anuitas Dan Flat

Angga Arisa

satu di antaraya adalah keuntungan diakui secara proporsional. Kemudian dalam Fatwa Dewan Syariah Nasional (DSN) No. 84/DSN-MUI/XII/2012 tentang Metode Pengakuan Keuntungan al-Tamwil bi alMurabahah (Pembiayaan Murabahah) di Lembaga Keuangan Syariah, keuntungan murabahah dapat dilakujkan secara proporsional (Thoriqoh Mubasyiroh) maupun anuitas (Thoriqoh al-HisabalTanazuliyyah/Thoriqoh al-Tanaqushiyyah) (Arisa, 2017).Dalam prakteknya, metode yang digunakan oleh bank syariah untuk menghitung margin (termasuk angsuran bulanan) adalah metode anuitas dan metode flat. Metode anuitas biasanya digunakan untuk pembiayaan murabahah yang mempunyai jangka waktu panjang (diatas 5 tahun), dan metode flat digunakan untukpembiayaan murabahah dengan jangkawaktu pendek (sampai dengan 5 tahun) (Rimadhani \& Erza, 2017).

Metode anuitas adalah suatu rangkaian pembayaran uang yang sama besarnya degan periode waktu yang sama untuk setiap pembayaran (Isnaini \& Marliyah, 2015). Berikut ini adalah contoh perhitungan anuitas untuk pembiayaan murabahah dengan harga pokok Rp 12.000.000,00, jangka waktu 12 bulan, serta besaran margin 22,15\% dari pokok.

\begin{tabular}{|c|r|r|r|r|r|}
\hline Bulan ke- & Pokok (Rp) & Margin (Rp) & Total Angsuran (Rp) & \multicolumn{1}{c|}{ Sisa Pokok (Rp) } & Akumulasi Margin (Rp) \\
\hline 0 & & & & 12.000 .000 & 221.500 \\
\hline 1 & 902.499 & 221.500 & 1.123 .999 & 11.097 .501 & 426.341 \\
\hline 2 & 919.158 & 204.841 & 1.123 .999 & 10.178 .343 & 614.217 \\
\hline 3 & 936.124 & 187.875 & 1.123 .999 & 9.242 .220 & 784.813 \\
\hline 4 & 953.403 & 170.596 & 1.123 .999 & 8.288 .816 & 937.810 \\
\hline 5 & 971.001 & 152.998 & 1.123 .999 & 7.317 .815 & 1.072 .885 \\
\hline 6 & 988.924 & 135.075 & 1.123 .999 & 6.328 .891 & 1.189 .706 \\
\hline 7 & 1.007 .178 & 116.821 & 1.123 .999 & 5.321 .713 & 1.287 .936 \\
\hline 8 & 1.025 .769 & 98.230 & 1.123 .999 & 4.295 .943 & 1.367 .232 \\
\hline 9 & 1.044 .703 & 79.296 & 1.123 .999 & 3.251 .240 & 1.427 .244 \\
\hline 10 & 1.063 .987 & 60.012 & 1.123 .999 & 2.187 .254 & 1.467 .617 \\
\hline 11 & 1.083 .626 & 40.373 & 1.123 .999 & 1.103 .628 & 1.487 .988 \\
\hline 12 & 1.103 .628 & 20.371 & 1.123 .999 & & $(0)$ \\
\hline Total & 12.000 .000 & 1.487 .988 & 13.487 .988 & & \\
\hline
\end{tabular}

\section{Gambar 2. Perhitungan Angsuran dan Akumulasi Margin dengan Metode Anuitas}

Dalam metode anuitas, jumlah angsuran setiap bulan adalah sama tetapi komposisi nominal pokok dan margin setiap bulannya berbeda (Latuconsina, 2016), untuk pokok dari kecil semakin membesar nominalnya, dan untuk margin dari besar semakin mengecil jumlahnya. Hal yang menarik dari metode anuitas ini adalah bank mendapatkan keuntungan lebih cepat. Contohnya adalah pada Gambar 2, saat bulan ke-6 (setengah daritotal jangka waktu pembiayaan) akumulasi margin bagi banksyariah adalah Rp 1.072.885,00 (72\% dari total margin). Hal ini sejalan dengan prinsip akuntasiyang adadi bank (baik bank syariah maupun bank konvensional), yaitu accrual basis untuk pembiayaan dengan tingkat kesehatan pembiayaan lancar (kolektibilitas 1) dan DPK/Dalam Perhatian Khusus (kolektibilitas 2), artinya bank sudah diperbolehkan secara akuntansi mengakui sebagai pendapatan untuk marginyang belum dibayar nasabah tetapi sudah munculdi sistem bank (core banking system). 
Khazanah Pendidikan Islam, Vol. 2 No. 3: 139-149

Konsep Al-Baaqiyaat As-Sholihat Dalam Murabahah: Penentuan Margin Serta Penggunaan Metode Perhitungan Anuitas Dan Flat

Angga Arisa

\section{Metode Perhitungan Margin dengan Metode Flat}

Dari contoh pembiayaan di atas (nominal Rp 12.000.000,00, jangka waktu 12 bulan, dan besaran margin $22,15 \%$ dari pokok), sebelum dihitung dengan metode flat maka perlu dihitung dulu prosentase flat yang ekuivalen dengan besaran margin $22,15 \%$ anuitas per tahun. Rumus konversi anuitas ke flat yang digunakanadalah sebagaiberikut:

$$
i=\frac{r(n+1)}{2 . n \cdot t}
$$

Dimana:

$$
\begin{array}{ll}
\mathrm{i} & =\text { prosentase margin flat per bulan } \\
\mathrm{r} & =\text { prosentase margin afektif per tahun } \\
\mathrm{t} & =\text { jangka waktu pembiayaan } \\
\mathrm{t} & =\text { konstanta }(12)
\end{array}
$$

Dengan menggunakan rumus diatas, maka didapatkan bahwa 22,15\% efektifpertahun ekuivalen dengan $1 \%$ flatperbulan. Contoh perhitungan angsuran dan akumulasi marginnya pada Gambar 3:

\begin{tabular}{|c|r|r|r|r|r|}
\hline Bulan ke- & Pokok (Rp) & Margin (Rp) & Total Angsuran (Rp) & \multicolumn{1}{l|}{ Sisa Pokok (Rp) } & Akumulasi Margin (Rp) \\
\hline 0 & & & & 12.000 .000 & 120.000 \\
\hline 1 & 1.000 .000 & 120.000 & 1.120 .000 & 11.000 .000 & 240.000 \\
\hline 2 & 1.000 .000 & 120.000 & 1.120 .000 & 10.000 .000 & 360.000 \\
\hline 3 & 1.000 .000 & 120.000 & 1.120 .000 & 9.000 .000 & 480.000 \\
\hline 4 & 1.000 .000 & 120.000 & 1.120 .000 & 8.000 .000 & 600.000 \\
\hline 5 & 1.000 .000 & 120.000 & 1.120 .000 & 7.000 .000 & 720.000 \\
\hline 6 & 1.000 .000 & 120.000 & 1.120 .000 & 6.000 .000 & 840.000 \\
\hline 7 & 1.000 .000 & 120.000 & 1.120 .000 & 5.000 .000 & 960.000 \\
\hline 8 & 1.000 .000 & 120.000 & 1.120 .000 & 4.000 .000 & 1.080 .000 \\
\hline 9 & 1.000 .000 & 120.000 & 1.120 .000 & 3.000 .000 & 1.200 .000 \\
\hline 10 & 1.000 .000 & 120.000 & 1.120 .000 & 2.000 .000 & 1.320 .000 \\
\hline 11 & 1.000 .000 & 120.000 & 1.120 .000 & 1.000 .000 & 1.440 .000 \\
\hline 12 & 1.000 .000 & 120.000 & 1.120 .000 & & - \\
\cline { 1 - 4 } Total & 12.000 .000 & 1.440 .000 & 13.440 .000 & & \\
\cline { 1 - 3 } & & & & &
\end{tabular}

\section{Gambar 3. Perhitungan Angsuran dan Akumulasi Margin dengan Metode Flat}

Dengan menggunakan metode flat, besaran angsuran bulanan tetap sama, kemudian komposisi pokok dan margin dalam angsuran bulanan juga sama. Hal yang menarik adalah a kumulasi pendapatan margin dengan metode flat ini lebih lambat dibandingkan metode anuitas. Sebagai contoh adalah pada bulan ke-6, akumulasi margin bagi bank adalah Rp 720.000,00 (50\% dari total margin) sedangkan pada metode anuitas di bulan yang sama akumulasi marginnya sudah mencapai Rp 1.072.885,00 (72\% dari total margin). Sedangkan total akumulasi margin relatif mendekati nilainya, perbedaan total akumulasi margin ini dikarenakan teknis pembulatan belakang koma pada saat melakukan konversi prosentase anuitas ke flat. 
Khazanah Pendidikan Islam, Vol. 2 No. 3: 139-149

Konsep Al-Baaqiyaat As-Sholihat Dalam Murabahah: Penentuan Margin Serta Penggunaan Metode Perhitungan Anuitas Dan Flat

Angga Arisa

\section{Penerapan Konsep Al-BaaqiyaatAs-Sholihat dalam Anuitas dan Flat}

Dari 2 jenis metode perhitungan margin tersebut, dari sisi bank syariah yang lebih memberikan manfaatadalah metode anuitaskarena pegakuan pendapatannya lebih cepat(komposisi margin besarke kecil) serta menahan laju penurunan pokok pembiayaan (komposisi pokok kecil ke besar). Hal ini akan membantu performa bank syariah yang tercermin dalam laporan keuangan, yaitu neraca untuk total pembiayaan, serta laporan laba rugi. Dari sisi nasabah sebenarnya sama saja antara anuitas dan flat sepanjang besaran prosentasemargin yang digunakan ekuivalen (Ismanto etal.,2019).

Anuitas akan bermasalah jika nasabah mengalami keterlambatan pembayaran, maka akan mengakibatkan komposisi pokok dan margin pada angsuran bulan -bulan berikutnya akan berubah sehingga berdampak pada sisa pokok pembiayaan pada saat jatuh tempo pembiayaan. Implikasinya adalah besaran total margin akan berubah menjadi lebih besar sehingga dikhawatirkan akan menjadi masalah hukum syariah, yaitu margin berubah menjadi bunga (Arisa, 2017).

Selain isu tersebut, potensi masalah juga bisa terjadi jika nasabah melakukan pelunasan maju. Dalam murabahah idealya pada saat nasabah melakukan pelunasan maju maka seluruh sisa pokok dan sisa margin dibayar semua karena sudah menjadi satu sebagai harga jual objek murabahah dari bank syariah ke nasabah. Akan tetapi, hal ini berdam pakpada nasabah yangmerasa prosuk murabahah kurang kompetitif dibandingkan produk perbankan konvensional, dimana pada saat melakukan pelunasan maju nasabah hanya membayar sisa pokok ditambah bunga berjalan dan pinalti. Oleh karena itu, supaya murabahah menjadi kompetitif maka pada saatpelunasan maju bank syariah dapat memberikan restitusi (pengembalian uang) kepada nasabah.

Hal yang perlu dikaji adalah metode perhitungan pemberian restitusi ini. Jika restitusi dihitung berdasarkan sisa margin yang belum dibayar dikalikan suatu prosentase tertentu, maka nasabah yang mendapatkan pembiayaan murabahah dengan metode flatdirugikan dibandingkan metodeanuitas.

\begin{tabular}{|c|r|r|r|r|}
\hline \multirow{2}{*}{ Bulan ke-- } & \multicolumn{2}{|c|}{ Metode Flat } & \multicolumn{2}{c|}{ Metode Anuitas } \\
\cline { 2 - 5 } & Akumulasi Margin (Rp) & Sisa Margin (Rp) & Akumulasi Margin (Rp) & Sisa Margin (Rp) \\
\hline 0 & & & & \\
\hline 1 & 120.000 & 1.320 .000 & 221.500 & 1.266 .488 \\
\hline 2 & 240.000 & 1.200 .000 & 426.341 & 1.061 .647 \\
\hline 3 & 360.000 & 1.080 .000 & 614.217 & 873.772 \\
\hline 4 & 480.000 & 960.000 & 784.813 & 703.176 \\
\hline 5 & 600.000 & 840.000 & 937.810 & 550.178 \\
\hline 6 & 720.000 & 720.000 & 1.072 .885 & 415.103 \\
\hline 7 & 840.000 & 600.000 & 1.189 .706 & 298.283 \\
\hline 8 & 960.000 & 480.000 & 1.287 .936 & 200.053 \\
\hline 9 & 1.080 .000 & 360.000 & 1.367 .232 & 120.757 \\
\hline 10 & 1.200 .000 & 240.000 & 1.427 .244 & 60.744 \\
\hline 11 & 1.320 .000 & 120.000 & 1.467 .617 & 20.371 \\
\hline 12 & 1.440 .000 & - & 1.487 .988 & - \\
\hline
\end{tabular}

\section{Gambar 4. Perbandingan Sisa Margin antara Metode Flat dan Anuitas}

Dari simulasi perhitungan pada Gambar 4, dicontohkan bahwa jika pada bulan ke-6 melakukan pelunasan maju maka sisa marginnya adalah $\mathrm{Rp} 720.000,00$ (dalam m etode flat) atau Rp 415.103,00 (dalam metode anuitas).Kemudian, kalau restitusi dihitung menggunakan prosentase dikali sisa margin, 
Khazanah Pendidikan Islam, Vol. 2 No. 3: 139-149

Konsep Al-Baaqiyaat As-Sholihat Dalam Murabahah: Penentuan Margin Serta Penggunaan Metode Perhitungan Anuitas Dan Flat

Angga Arisa

maka terbukti bahwa besaran sisa margin yang harus dibayar nasabah lebih banyak yang metode flat dibandingkan anuitas.

Terkait dengan kaidah al-baaqiyat as-sholihat, maka unsur kesesuaian syariah yang bisa diterapkan dalam hal iniadalah kesesuaiannya dengan nilai-nilai dasar ekoomi Islam. Salah satu nilai dasar ekonomi Islam adalah keadilan $(a d l)$, dimana maknaadil dalam Al-qur'an dapat diturunkan menjadi beberapa nilai turunan, diantaranya adalah persamaan kompensasi, persamaan hukum, moderat, dan proporsional (Yogyakarta, 2014). Nilai keadilan ini yang harus diimpelementasikan dalam murabahah, khususnya dalam metode perhitungan anuitas dan flat. Jika perhitungan dengan metode anuitas dan flat initidak bisa memberikan keadilan bagi bank syariah dan nasabah, metode ini berarti tidak sesuai dengan kaidah albaaqiyat as-sholihat. Supaya murabaah ini tetap bisa bernilai al-baaqiyat as-sholihat, maka yang perlu dilakukan adalah perlakuan yang sama kepada nasabah yang mendapatkan pembiayaan murabahah dengan metode anuitas maupun flat. Konkretnya adalah untuk perhitungan restitusi tidak boeh dihitung berdasarkan sisa margin yang belum dibayar nasabah, tetapi dihitung dari total margin yang disepakati. Jadi, restitusi yang diterima nasabah jika dibandingkan total margin yang sudah disepakati ketika akad adaah sama. Dampaknya adalah nasabah tidak ada yang dirugikan, kemudian bank syariah juga secara total tetap medapatkan total margin yang sama.

\section{SIMPULAN}

Dalam penentuan keuntungan dalam murabahah berupa margin, ketentuan dalam Al-quran dan hadits tidak ada yang melarang pengambilan margin dalam jual beli, bahkan tidak ada juga batasan besaran keuntungan/margin yang boleh diambil. Kemudian, dalam nash juga dijelaskan bahwa dalam Islam tidak ada perintah untuk menetapkan harga karena harga dianggap berasal dari Allah. Penentuan harga diserahkan pada mekanisme pasar dimana tidak boleh ada intervensi dari pemegang otoritas sepanjang mekanisme pasar berlangsung secara normal dan wajar. Dalam konteks penentuan besaran margin murabahah, mekanisme pasar artinya margin dihitung berdasarkan struktur dana di bank syariah tersebut serta penerimaan pasar (nasabah) terhadap besaran margin tersebut sehingga margin tetap harus kompetitif jika dibandingkan dengan bank syariah lainnya bahkan dibandingkan dengan suku bunga perbankan konvensional.jika hal-hal tersebut di atas terpenuhi, hal ini berarti pengenaan margin serta besaran margin dalam murabahah tidak bertentangan dengan syariah sehingga murabahah sesuai dengan kaidah al-baaqiyat as-sholihat(bernilai amal sholeh).

Kemudian, metode perhitungan margin dalam prakteknya di perbankan syariah ada yang menggunakan metode anuitas dan flat. Kedua metode ini hanyalah metode hitung sehingga tidak menjadikan margin sama dengan bunga. Supaya metode hitung(anuitas dan flat) ini bernilai al-baaqiyat as-sholihat maka harus sesuai dengan salah satu nilai dasar ekonomi syariah, yaitu keadilan ( $a d l)$. Dari sudut pandang bank syariah, metode anuitas lebih menguntungkan karena pengakuan akumulasi pendapatan margin lebih cepat dan lebih besar dibandingkan metode flat, kecuali pada saat jatuh tempo besaran akumulasi pendapatan margin hamper sama. Dari sudut pandang nasabah, jumlah angsuran metode anuitas dan flat hampir sama sehingga nasabah tidak dirugikan. Kecuali ketika nasabah melakukan pelunasan maju dan nasabah mendapatkan restitusi (pengurangan atau pengembalian) dari pembayaran sisa margin, maka nasabah akan dirugikan dengan menggunakan metode flat dibandingkan metode anuitas. Solusinya adalah perhitungan restitusiatas sisa margin tersebutharus dihitung dari total margin yang telah disepakati di awal akad murabahah, bukan dihitung dari sisa margin. Jika hal ini 
Khazanah Pendidikan Islam, Vol. 2 No. 3: 139-149

Konsep Al-Baaqiyaat As-Sholihat Dalam Murabahah: Penentuan Margin Serta Penggunaan Metode Perhitungan Anuitas Dan Flat

Angga Arisa

dilakukan, berarti prinsip al-adalah (keadilan) telah diterapkan dalam murabahah sehingga bisa dikatakan murabahah ini telah sesuai dengan syariah sehingga bernilai al-baaqiyat as-sholihat (amal sholeh).

\section{DAFTARPUSTAKA}

Adnan, M. A., \& Purwoko, D. (2015). Analisis faktor-faktor yang mempengaruhi rendahnya pembiayaan mudharabah menurut perspektif manajemen bank syariah dengan pendekatan kritis. Journal of Accounting and Investment, 14(1), 14-31.

Al-Faizin, A. W., \& Akbar, N. (2018). Tafsir Ekonomi Kontemporer: Menggali Teori Ekonomi dari AyatAyat Al-Qur'an. Jakarta: Gema Insani Press.

Annisa, A. A. (2013). Penetapan Harga Jual Produk Murabahah Studi Kasus di BMT Rama Salatiga. Muqtasid: Jurnal Ekonomi Dan Perbankan Syariah, 4(2), 239-266.

Arisa, A. (2017). Analisis Perbandingan Pendekatan Anuitas dan Flat dalam Murabahah. In Prosiding Seminar Nasional Ekonomi dan Keuangan Syariah di Indonesia: Antara Cita-Cita dan Realita. Sps UIN Jakarta Press.

Hidayatulloh, M. K. (2018). KONSEP DAN METODE TAFSIR TEMATIK (STUDI KOMPARASI ANTARA AL-KUMI DAN MUSHTHOFA MUSLIM). Al-Bayan: Jurnal Studi Ilmu Al-Qur'an Dan Tafsir, $3(2)$.

Ismanto, H., Widiastuti, A., Muharam, H., Pangestuti, I. R. D., \& Rofiq, F. (2019). Perbankan Dan Literasi Keuangan. Deepublish.

Isnaini, H., \& Marliyah, R. S. (2015). Hadis-Hadis Ekonomi. Jakarta: Prenadamedia Group.

Latuconsina, Y. M. (2016). Mengungkap Fenomena Potongan Angsuran Murabahah di Perbankan Syariah.Journal of Accounting and Investment, 17(2), 132-140.

Nisa, C. (2020). Pengukuran Laba Perusahaan Melalui Bagi Hasil Pembiayaan Musyarakah dan Margin Murabahah. Khazanah Sosial, 2(2), 88-93.

ojk. (2018). Statistik Perbankan Syariah: September $2018 . \quad$ 0jk.Go.Id. https://www.ojk.go.id/id/kanal/syariah/data-dan-statistik/statistik-perbankansyariah/Default.aspx

Rachmawati, E. N., \& Darmaya, W. (2018). Analisis Penetapan Margin Pada Pembiayaan Murabahah Dan Nisbah Bagi Hasil Pada Pembiayaan Mudharabah di Bmt Al-Ittihad Pekanbaru. Syarikat: Jurnal Rumpun Ekonomi Syariah, 1(2), 76-89.

Rimadhani, M., \& Erza, O. (2017). Analisis Variabel-variabel Yang Mempengaruhi Pembiayaan Murabahah Pada Bank Syariah Mandiri Periode 2008.01-2011.12. Media Ekonomi, 19(1), $27-52$.

Sugiyono. (2013). Memahami Penelitian Kualitatif. CV. Alfabeta.

Suprihatin, S., Ibdalsyah, I., \& Tanjung, H. (2019). ANALISIS PEMIKIRAN IMAM AL -GHAZALI MENGENAI MEKANISME DAN ETIKA PERILAKU PASAR. Kasaba: Jurnal Ekonomi Islam, 11(1), 42-57.

Turmudi, M. (2016). Manajemen Penyelesaian Pembiayaan Bermasalah pada Lembaga Perbankan Syariah. Li Falah: Jurnal Studi Ekonomi Dan Bisnis Islam, 1(1), 95-106.

Yogyakarta, P. P. dan P. E. I. (P3EI) U. I. I. (2014). Ekonomi Islam. Raja Grafindo Persada. 